\title{
Perception and Expectation of Viewers and Proposed Business Models For Local TV Stations: Case of Internet Local TV Stations in West Java Province-Indonesia
}

\author{
UMI KALTUM, WA O. ZUSNITA, MERITA BERNIK \\ Department of Management and Business, Universitas Padjadjaran, Bandung 40132, Indonesia \\ Email correspondence: umi.kaltum@unpad.ac.id
}

\begin{abstract}
Local content is an important resource for Indonesia because it has economic as well as cultural values. Local content has the value of local wisdom, believed to be able to build a strong national identity and is able to survive amid the uncertainty era. Presently, the Indonesian local content barely exists, being hit by the global content in various media. Local television, closely related to the content area, is expected to encourage the growth of local content from all regions of the country. This research is aimed at determining the role of internet local TV in West Java in developing the local content which has global competitiveness. This can then be utilized by all local TV stations in Indonesia to expand the broadcast nationally and globally by using the Internet television technology. The method used is a descriptive survey using quantitative and qualitative research approach. The sample consists of 422 viewers and 12 local TV stations in West Java. The results obtained are the perceptions and expectations of the local TV viewers in West Java from the aspect of Quality Service with the dimensions of tangibility, Assurance, Empathy, Reliability, and Responsiveness, as well as the Business Model Canvas (BMC) of local TV stations in West Java.
\end{abstract}

Key words: local TV station, internet local TV, local content, quality service, business model canvas.

\section{Persepsi dan Harapan Pemirsa dan Model Bisnis yang Diusulkan Untuk Stasiun TV Lokal: Kasus Stasiun TV Lokal Internet di Provinsi Jawa Barat-Indonesia}

\begin{abstract}
Abstrak
Konten lokal merupakan sumberdaya penting bagi bangsa Indonesia karena memiliki nilai ekonomi sekaligus budaya. Konten lokal memiliki nilai kearifan lokal yang dipercaya mampu membangun jati diri bangsa yang kokoh dan mampu bertahan ditengah era ketidakpastian. Saat ini konten lokal Indonesia semakin tenggelam dengan membanjirnya konten global yang masuk melalui berbagai media. Televisi lokal yang identik dengan konten daerah sangat diharapkan peranannya dalam mendorong tumbuhnya konten lokal dari seluruh wilayah di tanah air. Penelitian ini bertujuan untuk mengetahui peran tv lokal internet di Jawa Barat dalam mengangkat konten lokal berdaya saing global yang selanjutnya dapat dimanfaatkan oleh seluruh televisi lokal di Indonesia untuk memperluas jangkauan siar secara nasional dan global dengan menggunakan teknologi televisi internet. Metode penelitian yang digunakan adalah descriptive survey, dengan menggunakan pendekatan riset kuantitatif dan kualitatif, sampel terdiri dari 422 permirsa dan 12 TV lokal di Jawa Barat. Hasil penelitaian diperoleh persepsi dan harapan pemirsa terhadap TV lokal di Jawa Barat dari aspek Quality Service dengan dimensi Tangibility, Assurance, Empathy, Reliability, dan Responsiveness, serta Model Bisnis Canvas (BMC) TV Lokal jawa Barat.
\end{abstract}

Kata kunci: televisi lokal, televisi lokal internet, konten lokal, layanan berkualitas, model bisnis canvas 
Jurnal Bisnis \& Manajemen, 2018, Vol. XIX, No. 1, 37-46

Available at: http://journal.feb.unpad.ac.id/index.php/jbm

\section{INTRODUCTION}

Local content is an essential resource for Indonesia because it has economic as well as cultural values. Local content has the value of local wisdom, believed to be able to build a strong national identity and is able to survive amid the uncertainty era. Indonesia is a nation rich in local moral values, but the reality today shows that local content is more difficult to be accessed than many foreign contents as broadcasted on TV and internet media. The need for the local content is becoming increasingly difficult to be fulfilled when we live outside our region or when we will abroad, resulting in a separation process of local culture systematically (Kaltum and Widodo, 2016).

The Local TV which generally has a regionalism mission is expected to encourage the growth of local content from all areas of Indonesia. But many of the local TV stations are in tough condition, shown by the fact that more than 200 local TV stations can only absorb $2.5 \%$ of all advertising spending which is the source of free-to-air (FTA) income. This causes many local TV stations suffer a financial loss and unable to produce TV programs which can compete in the national and global industry.

The limitation in broadcast coverage is considered to be the main factor causing the local TV difficult to develop. Some local TV stations have improved the broadcast coverage via satellite, but this method cannot be followed by others because of the expensive satellite channel rent. Some local TV stations have also expanded through the internet streaming but this is a new technology requiring a considerable adaptation, resulting many local TV stations unable organize it independently. There is a need for an aggregator system that can help extend the coverage of local TV broadcasting over the Internet.

The current development of information technology enables digital multimedia content to be distributed via the internet effectively. The availability of larger bandwidth access, the smarter and more powerful receiving device, as well as the more efficient compression technology, allow the internet TV service to be enjoyed more comfortably in various media players. Besides, a variety of access connections enable us to enjoy TV programs from anywhere and
JURNAL BISNIS \& MANAJEMEN

ISSN 1412 - 3681

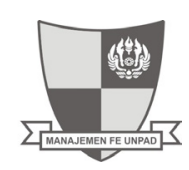

anytime . Currently, the internet TV can be enjoyed by using various terminals such as PC/laptop, tablet/ iPad, smartphones, smart TVs, set-top-box, etc. Various access connections such as fixed, wireless, and mobile connections are also available easily.

The improvement in broadcast coverage has the potential for expanding the market and increasing the number of viewers in order to increase the income from advertising. Nielsen's Southeast Asia Quarterly Advertising Index revealed that in the third quarter of 2011, the Indonesia advertising spending was the largest in Southeast Asia . Media ad spending in 2011 reached IDR 80.2 trillion and it was expected to grow by $14.71 \%$ to IDR 92 billion in 2012. More than $60 \%$, or about IDR 50 trillion of the media advertising expenditure was absorbed by the TV media. This potentially gives hope for local TV stations to extend the reach so they increase their economic value and promote the local TV industry in general.

Related to the problems and potential solutions that can be done, we conducted a study to foster the local content and increase the economic value of the local TV industry in Indonesia through the globalization of local TV content using internet TV technology. This study was conducted by involving academic institutions, research institutions, industry players, local TV associations, and government agencies. All parties involved in the research consortium of the internet local TV. Thus, the problem formulations of this research are as follows:

First, How is the perception and expectation of the viewers on Local TV in West Java

Second, How is the business model canvas of Local TV stations in West Java which enables them to develop in order to have global competitiveness

\section{LITERATURE REVIEW}

There are two main concepts used in this research, which are related to Service Quality and Business Model Canvas.

\section{Service Quality}

Heizer, Render, and Munson (2016) stated that the quality is the ability of goods or services to meet customer needs. Metters et al (2006) stated that quality is an essential element that should be 
JURNAL BISNIS \& MANAJEMEN

ISSN 1412 - 3681

improved to differ from competitors. They stated that the quality of service focuses on addressing the needs and desires of customers and accuracy of delivery to compensate customers' expectations. Thus, in producing the service product specification, the company should not only consider management decisions, but also consider the expectations or opinions of its customers.

The opinion of Heizer, Render, and Munson (2016) regarding the service quality is well-known as SERVQUAL. It is a widely used instrument providing a direct comparison between the expectation of the customer service and the actual service provided. SERVQUAL focuses on the gap between the expectation of the customer service and the service delivered. The dimensions of SERVQUAL are tangibility, empathy, reliability, responsiveness, and assurance.

Zeithaml and Bitner (2003:85) mentioned that, 'Service quality is a focused evaluation that reflects the customer's perception of specific dimensions of service namely reliability, responsiveness, assurance, empathy, tangibles. Based on the assessment of service quality provided to the customers, business operators are able to identify problem quickly, improve their service and better assess client expectation.

According to Parasuraman, Zeithaml, and Berry (1988), it is during the service delivery that the quality of services is assessed and the contact with each customer implies as a chance to satisfy or dissatisfy the customer, a moment of truth. They defined customer satisfaction with regards to service as 'by comparing perceptions of service received with expectations of service desired.' They also mentioned that an excellent quality of service is perceived when expectations are exceeded and on the other hand, service quality is considered as unacceptable when expectations are not met. Lastly, quality is satisfactory when perceived service confirmed expectations. In addition, Parasuraman, Zeithaml, and Berry (1988) introduced five dimensions which led to the development of SETVQUAL, these dimensions are as follows:

Tangibles: These include the appearance of employees, physical facilities being offered and equipment which form part of service experience.
Jurnal Bisnis \& Manajemen, 2018, Vol. XIX, No. 1, 37-46

Available at: http://journal.feb.unpad.ac.id/index.php/jbm

Reliability: The way the service is being delivered, that is, the ability to deliver the promised service precisely and consistently.

Responsiveness: Willingness to help customers, respond to their queries and also to provide rapid service to them.

Assurance: Understanding and courtesy of staffs and their capability to inspire trust and confidence.

Empathy: Helpful, care about the customers' requirements and the firm provides individualised attention to its customers with compassion.

\section{Business Model Canvas}

There are several ways to improve the quality of service so that the service provider can meet the desires of consumers. One of the methods for improving the quality of service is by using a business model canvas which was first introduced by Osterwalder and Pigneur (2010) in his book Business Model Generation. This is an analytical tool that can help us find the right business model. They attempted to explain a simple framework to present the crucial elements contained in a business model.

Wheelen et al (2015) defined that business model is a company's method for making money in the current business environment. It includes the key structural and operational characteristics of a firm how it earns revenue and makes a profit. A business model is usually composed of five elements: Who it serves, What it provides, How it makes money, How it differentiates and sustains competitive advantage, How it provides its product/service. The simplest business model is to provide a good or service that can be sold such that revenues exceed costs and all expenses.

A review on business model frameworks can be found in Krumeich et al. (2012). In the following some frameworks are introduced.

Business reference model; is a reference model, concentrating on the architectural aspects of the core business of an enterprise, service organization or government agency.

Component business model; Technique developed by IBM to model and analyze an enterprise. It is a logical representation or map of business components or "building blocks" and can be depicted on a single page. It can be used to analyze the alignment of 
Jurnal Bisnis \& Manajemen, 2018, Vol. XIX, No. 1, 37-46

Available at: http://journal.feb.unpad.ac.id/index.php/jbm

enterprise strategy with the organization's capabilities and investments, identify redundant or overlapping business capabilities, etc.

Industrialization of services business model; Business model used in strategic management and services marketing that treats service provision as an industrial process, subject to industrial optimization procedures.

Business Model Canvas; Developed by Osterwalder and Pigneur (2010) and 470 practitioners from 45 countries, the business model canvas is one of the most used frameworks for describing the elements of business models.

Osterwalder \& Pigneur (2010) stated that the Business Model Canvas is a business management strategy that allows us to describe, design and then sums up the aspects of the business into one unified business strategy.

At glance, the actual flow of the business model canvas is quite simple. Broadly speaking, the plot flows from one business element to the next important element. The business element which is the soul of the business model canvas is outlined below.

Business Model Canvas is a business model which consists of nine blocks of the business activity area. This has the goal to map out a strategy to build a strong business so the company can win the competition and be successful in the long term. The nine-block models in Business Model Canvas are taken together as a single business entity.

These nine block models are:

\section{Customer Segment}

When running the business, the organization should first designate who should be served. The organization may set to serve one or more segments. The determination of the segment will determine other components in the business model.

\section{Value Proposition}

Value Proposition is a benefit offered by the organization to the market segment served. The value proposition surely will determine the selected customer segment or otherwise. Value Proposition will also affect other components such as the Channel and Customer Relationship.

\section{Channels}

Channels are the means for an organization to deliver Value Proposition to the served Customer Segment. Channels function in several stages ranging from customer awareness to the after-sales service. Two other elements that must be considered carefully in making Channel model is the Value Proposition and Customer Segment.

\section{Revenue Stream}

Revenue Stream is considered as the most vital component. Generally, an organization generates revenue from customers. Yet many organizations are able to create income from other sources, not just from customers.

\section{Customer Relationship}

Customer Relationship is the way of an organization to create a bond with its customers.

\section{Key Activities}

Key Activities are the main activities of the organization to create Value Proposition.

\section{Key Resources}

Key Resources are the organization's resources used to realize the value proposition. Generally, these are human resources, technology, equipment, channel, and brand.

\section{Key Partnership}

Key Partnership is a resource needed by the organization to realize the value proposition, but it is not owned by the organization. The utilization of Key Partnership of a company can be outsourcing, joint venture, joint operation, or strategic alliances.

\section{Cost Structure}

Cost Structure is the composition of the costs to operate the organization to realize the value proposition provided to customers. An efficient cost structure is a key to the profitable organization. MaRS (2012) propose that business model design includes the modelling and description of a company's (1) value propositions, (2) target customer segments, (3) distribution channels, (4) customer relationships, (5) value configurations, (6) core capabilities, (7) partner network, (8) cost structure, and (9) revenue model.

\section{METHODS}

The method of this research is descriptive survey using quantitative and qualitative research approach. The population of this study is all local TV viewers and 
Jurnal Bisnis \& Manajemen, 2018, Vol. XIX, No. 1, 37-46

Available at: http://journal.feb.unpad.ac.id/index.php/jbm

local TV stations in west Java. Based on the Slovin interviews with TV station CEOs and Focus discussion formula the sample is determined as 422 viewers and 12 TV stations. The sampling technique used is purposive random sampling. group with teams from each local TV Station.

\section{RESULTS AND DISCUSSION}

This study uses primary and secondary data. Primary data were obtained from questionnaires both online and offline. The offline questionnaires were distributed to the Local TV viewers in West Java. Qualitative data collection was conducted by in-depth

\section{Perception and Expectation of Local TV Viewers in West Java}

The followings are the mode of all respondent answers representing the perception and expectation of the local TV viewers in West Java.

Table 1. Mode of Answers of Local TV Viewers in West Java (Perception Part)

\begin{tabular}{|c|c|c|c|c|c|c|c|}
\hline \multirow{2}{*}{ No. } & \multirow{2}{*}{ Statement } & \multicolumn{2}{|c|}{$\mathbf{N}$} & \multirow{2}{*}{ Mean } & \multirow{2}{*}{ Median } & \multirow{2}{*}{ Mode } & \multirow{2}{*}{$\begin{array}{l}\text { Interpretation of } \\
\text { Mode }\end{array}$} \\
\hline & & Valid & Missing & & & & \\
\hline 1 & Good/clear visual quality (picture) & 422 & 0 & 2.67 & 3.00 & 3 & Agree \\
\hline 2 & Good/clear audio quality (sound) & 422 & 0 & 2.76 & 3.00 & 3 & Agree \\
\hline 3 & Stable TV channel signal (minimum service interruption) & 422 & 0 & 2.63 & 3.00 & 3 & Agree \\
\hline 4 & $\begin{array}{l}\text { Graphic design (user interface) of each program is interesting (including animation } \\
\text { touch) }\end{array}$ & 422 & 0 & 2.52 & 2.50 & 2 & disagree \\
\hline 5 & $\begin{array}{l}\text { There is digital TV feature on the official website of the company enabling mobile } \\
\text { access to TV channel }\end{array}$ & 422 & 0 & 2.53 & 3.00 & 3 & Agree \\
\hline 6 & $\begin{array}{l}\text { Easy access to TV channel (it does not require tools such as a satellite dish to access } \\
\text { the channel frequency) }\end{array}$ & 422 & 0 & 2.63 & 3.00 & 3 & Agree \\
\hline 7 & Costume of the broadcaster and or decoration (studio or stage) is attractive & 422 & 0 & 2.64 & 3.00 & 3 & agree \\
\hline 8 & Program content is entertaining & 422 & 0 & 2.76 & 3.00 & 3 & agree \\
\hline 9 & Varied program types & 422 & 0 & 2.54 & 3:00 & 2 & disagree \\
\hline 10 & Ads are in accordance with the program being aired & 422 & 0 & 2.47 & 2.00 & 3 & agree \\
\hline 11 & Ads being aired are rational in terms of duration & 422 & 0 & 2.74 & 3.00 & 3 & Agree \\
\hline 12 & There is a variety of TV programs for a wide range of viewers & 422 & 0 & 2.78 & 3.00 & 3 & Agree \\
\hline 13 & Broadcast time is right for each program & 422 & 0 & 2.77 & 3.00 & 3 & Agree \\
\hline 14 & TV channel gives positive messages to the audiences to become better society & 422 & 0 & 3.07 & 3.00 & 3 & Agree \\
\hline 15 & The duration of daily broadcast is adequate & 422 & 0 & 2.83 & 3.00 & 3 & Agree \\
\hline 16 & Showtime of the programs are according to the schedule already set & 422 & 0 & 2.81 & 3.00 & 3 & Agree \\
\hline 17 & Information in news program is accurate and reliable & 422 & 0 & 3.00 & 3.00 & 3 & Agree \\
\hline 18 & $\begin{array}{l}\text { Entertainment programs aired are not offensive in terms of ethnicity, religion, race } \\
\text { and intergroup relations }\end{array}$ & 422 & 0 & 3.08 & 3.00 & 3 & Agree \\
\hline 19 & All TV programs aired have parental guide & 422 & 0 & 2.93 & 3.00 & 3 & Agree \\
\hline 20 & All programs have passed the censorship of the authority & 422 & 0 & 3.03 & 3.00 & 3 & Agree \\
\hline 21 & $\begin{array}{l}\text { Providing customer call service (interaction service) to receive complaints related } \\
\text { to the programs }\end{array}$ & 422 & 0 & 2.61 & 3.00 & 3 & Agree \\
\hline 22 & Giving apology and clarification when delivering inaccurate reporting & 422 & 0 & 2.79 & 3:00 & 3 & Agree \\
\hline 23 & Airing programs with local wisdom characteristics (the origin of TV station) & 422 & 0 & 3.17 & 3.00 & 3 & Agree \\
\hline 24 & Using local language in one or more TV programs & 422 & 0 & 3.05 & 3.00 & 3 & Agree \\
\hline 25 & All presenters and news anchor uphold the value of civility & 422 & 0 & 3.21 & 3.00 & 3 & Agree \\
\hline 26 & Presenter of every program can convey information properly & 422 & 0 & 3.12 & 3.00 & 3 & Agree \\
\hline 27 & There are programs that are not available in national and international TV stations & 422 & 0 & 3.01 & 3.00 & 3 & Agree \\
\hline 28 & $\begin{array}{l}\text { Broadcasting holiday greeting and/or customizing the display in any religious } \\
\text { holidays }\end{array}$ & 422 & 0 & 3.16 & 3.00 & 3 & Agree \\
\hline 29 & Delivering informative program and providing comprehensive knowledge & 422 & 0 & 3.12 & 3.00 & 3 & Agree \\
\hline 30 & Broadcasting Indonesian culture (either local culture or other cultures) & 422 & 0 & 3.20 & 3.00 & 3 & Agree \\
\hline 31 & Delivering meaningful and educative programs promoting good behavior & 422 & 0 & 3.14 & 3.00 & 3 & Agree \\
\hline
\end{tabular}

Source: Processed data (2017) 
Jurnal Bisnis \& Manajemen, 2018, Vol. XIX, No. 1, 37-46

Available at: $h$ ttp://journal.feb.unpad.ac.id/index.php/jbm
JURNAL BISNIS \& MANAJEMEN

ISSN 1412 - 3681

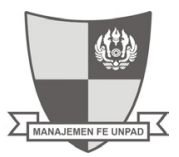

From the table above, it is known that the viewers of local TV in West Java assess that the aspects of service quality of local TV are pretty good. This can be seen from the mean, median, and mode values. The aspects which are considered low quality are less digital touch and animation in graphic design (user interface) of the programs. Besides, the programs are deemed not varied and there is a little creativity in making the programs in order to attract viewers. Here is a table of viewer's expectation to the Local TV in

\section{West Java.}

Table 2 shows that the expectation of most of the local TV viewers in West Java is not fulfilled by the local TV stations. This is evidenced by the fact that most of the quality aspects still need improvement. If those quality aspects are improved, the local TV stations will be more attractive to the viewers and be able to compete with national and global TV stations. Here is the table showing the gaps between perception

Table 2. Mode of Answers of Local TV Viewers in West Java (Expectation Part)

\begin{tabular}{|c|c|c|c|c|c|c|c|}
\hline \multirow{2}{*}{ No. } & \multirow{2}{*}{ Statement } & \multicolumn{2}{|c|}{$\mathbf{N}$} & \multirow{2}{*}{ Mean } & \multirow{2}{*}{ Median } & \multirow{2}{*}{ Mode } & \multirow{2}{*}{$\begin{array}{l}\text { Interpretation of } \\
\text { Mode }\end{array}$} \\
\hline & & Valid & Missing & & & & \\
\hline 1 & Good/clear visual quality (picture) & 422 & 0 & 3.36 & 3.00 & 4 & Very necessary \\
\hline 2 & Good/clear audio quality (sound) & 422 & 0 & 3.40 & 4.00 & 4 & Very necessary \\
\hline 3 & Stable TV channel signal (minimum service interruption) & 422 & 0 & 3.40 & 4.00 & 4 & Very necessary \\
\hline 4 & $\begin{array}{l}\text { Graphic design (user interface) of each program is interesting (including animation } \\
\text { touch) }\end{array}$ & 422 & 0 & 3.27 & 3.00 & 3 & Necessary \\
\hline 5 & $\begin{array}{l}\text { There is digital TV feature on the official website of the company enabling mobile } \\
\text { access to TV channel }\end{array}$ & 422 & 0 & 3.11 & 3.00 & 3 & Necessary \\
\hline 6 & $\begin{array}{l}\text { Easy access to TV channel (it does not require tools such as a satellite dish to access } \\
\text { the channel frequency) }\end{array}$ & 422 & 0 & 3.28 & 3.00 & 4 & Very necessary \\
\hline 7 & Costume of the broadcaster and or decoration (studio or stage) is attractive & 422 & 0 & 3.26 & 3.00 & 3 & Necessary \\
\hline 8 & Program content is entertaining & 422 & 0 & 3.32 & 3.00 & 3 & Necessary \\
\hline 9 & Varied program types & 422 & 0 & 3.34 & 4.00 & 4 & Very necessary \\
\hline 10 & Ads are in accordance with the program being aired & 422 & 0 & 3.13 & 3.00 & 3 & Necessary \\
\hline 11 & Ads being aired are rational in terms of duration & 422 & 0 & 3.26 & 3.00 & 3 & Necessary \\
\hline 12 & There is a variety of TV programs for a wide range of viewers & 422 & 0 & 3.36 & 3.00 & 4 & Very necessary \\
\hline 13 & Broadcast time is right for each program & 422 & 0 & 3.44 & 3.00 & 4 & Very necessary \\
\hline 14 & TV channel gives positive messages to the audiences to become better society & 422 & 0 & 3.49 & 4.00 & 4 & Very necessary \\
\hline 15 & The duration of daily broadcast is adequate & 422 & 0 & 3.32 & 3.00 & 3 & Necessary \\
\hline 16 & Showtime of the programs are according to the schedule already set & 422 & 0 & 3.40 & 3.00 & 4 & Very necessary \\
\hline 17 & Information in news program is accurate and reliable & 422 & 0 & 3.48 & 4.00 & 4 & Very necessary \\
\hline 18 & $\begin{array}{l}\text { Entertainment programs aired are not offensive in terms of ethnicity, religion, race } \\
\text { and intergroup relations }\end{array}$ & 422 & 0 & 3.51 & 4.00 & 4 & Very necessary \\
\hline 19 & All TV programs aired have parental guide & 422 & 0 & 3.46 & 4.00 & 4 & Very necessary \\
\hline 20 & All programs have passed the censorship of the authority & 422 & 0 & 3.52 & 4.00 & 4 & Very necessary \\
\hline 21 & $\begin{array}{l}\text { Providing customer call service (interaction service) to receive complaints related } \\
\text { to the programs }\end{array}$ & 422 & 0 & 3.33 & 3.00 & 4 & Very necessary \\
\hline 22 & Giving apology and clarification when delivering inaccurate reporting & 422 & 0 & 3.39 & 3.00 & 4 & Very necessary \\
\hline 23 & Airing programs with local wisdom characteristics (the origin of TV station) & 422 & 0 & 3.51 & 4.00 & 4 & Very necessary \\
\hline 24 & Using local language in one or more TV programs & 422 & 0 & 3.39 & 4.00 & 4 & Very necessary \\
\hline 25 & All presenters and news anchor uphold the value of civility & 422 & 0 & 3.50 & 4.00 & 4 & Very necessary \\
\hline 26 & Presenter of every program can convey information properly & 422 & 0 & 3.46 & 4.00 & 4 & Very necessary \\
\hline 27 & There are programs that are not available in national and international TV stations & 422 & 0 & 3.42 & 4.00 & 4 & Very necessary \\
\hline 28 & $\begin{array}{l}\text { Broadcasting holiday greeting and/or customizing the display in any religious } \\
\text { holidays }\end{array}$ & 422 & 0 & 3.44 & 4.00 & 4 & Very necessary \\
\hline 29 & Delivering informative program and providing comprehensive knowledge & 422 & 0 & 3.52 & 4.00 & 4 & Very necessary \\
\hline 30 & Broadcasting Indonesian culture (either local culture or other cultures) & 422 & 0 & 3.57 & 4.00 & 4 & Very necessary \\
\hline 31 & Delivering meaningful and educative programs promoting good behavior & 422 & 0 & 3.56 & 4.00 & 4 & Very necessary \\
\hline
\end{tabular}

Source: Processed data (2017) 
JURNAL BISNIS \& MANAJEMEN

ISSN 1412 - 3681

and expectation of local TV viewers regarding the programs aired by local TV stations in West Java.

The table 3 shows that all programs of local TV stations in West Java could not satisfy their viewers as seen from the negative values of the gap score between perception and expectation. This condition shows that all the dimensions of service quality of the local TV programs in West Java, i.e. tangibility, empathy, reliability, responsiveness, and assurance
Jurnal Bisnis \& Manajemen, 2018, Vol. XIX, No. 1, 37-46

Available at: http://journal.feb.unpad.ac.id/index.php/jbm are considered not optimal and need to be improved.

Business Model Canvas of Local TV Stations in West Java

In this study, there are two types of Local TV business models in West Java; 1) Local TV with public TV business model and 2) Local TV with private TV business model. Local Public TV is a TV owned and operated by a state-owned enterprise for the purpose of disseminating regional development information.

Table 3. Gap between Perception and Expectation of Local TV Viewers in West Java

\begin{tabular}{|c|c|c|c|c|}
\hline No. & Statement of & Perception & Expectation & Gap Score \\
\hline 1 & Good/clear visual quality (picture) & 2.668 & 3.362 & -0.694 \\
\hline 2 & Good/clear audio quality (sound) & 2.755 & 3.400 & -0.645 \\
\hline 3 & Stable TV channel signal (minimum service interruption) & 2.630 & 3.396 & -0.765 \\
\hline 4 & $\begin{array}{l}\text { Graphic design (user interface) of each program is interesting (including animation } \\
\text { touch) }\end{array}$ & 2.524 & 3.275 & -0.751 \\
\hline 5 & $\begin{array}{l}\text { There is digital TV feature on the official website of the company enabling mobile } \\
\text { access to TV channel }\end{array}$ & 2.526 & 3.114 & -0.588 \\
\hline 6 & $\begin{array}{l}\text { Easy access to TV channel (it does not require tools such as a satellite dish to access } \\
\text { the channel frequency) }\end{array}$ & 2.633 & 3.279 & -0.647 \\
\hline 7 & Costume of the broadcaster and or decoration (studio or stage) is attractive & 2.637 & 3.258 & -0.621 \\
\hline 8 & Program content is entertaining & 2.761 & 3.25 & -0.564 \\
\hline 9 & Varied program types & 2.538 & 3.341 & -0.803 \\
\hline 10 & Ads are in accordance with the program being aired & 2.467 & 3.126 & -0.659 \\
\hline 11 & Ads being aired are rational in terms of duration & 2.744 & 3.256 & -0.512 \\
\hline 12 & There is a variety of TV programs for a wide range of viewers & 2.777 & 3.363 & -0.585 \\
\hline 13 & Broadcast time is right for each program & 2.770 & 3.436 & -0.666 \\
\hline 14 & TV channel gives positive messages to the audiences to become better society & 3.073 & 3.486 & -0.412 \\
\hline 15 & The duration of daily broadcast is adequate & 2.829 & 3.325 & -0.495 \\
\hline 16 & Showtime of the programs are according to the schedule already set & 2.808 & 3.396 & -0.588 \\
\hline 17 & Information in news program is accurate and reliable & 2.995 & 3.474 & -0.478 \\
\hline 18 & $\begin{array}{l}\text { Entertainment programs aired are not offensive in terms of ethnicity, religion, race } \\
\text { and intergroup relations }\end{array}$ & 2.083 & 3.504 & -0.427 \\
\hline 19 & All TV programs aired have parental guide & 2.929 & 3.464 & -0.536 \\
\hline 20 & All programs have passed the censorship of the authority & 3.033 & 3.517 & -0.483 \\
\hline 21 & $\begin{array}{l}\text { Providing customer call service (interaction service) to receive complaints related } \\
\text { to the programs }\end{array}$ & 2.614 & 3.331 & -0.718 \\
\hline 22 & Giving apology and clarification when delivering inaccurate reporting & 2.787 & 3.383 & -0.597 \\
\hline 23 & Airing programs with local wisdom characteristics (the origin of TV station) & 3.166 & 3.512 & -0.346 \\
\hline 24 & Using local language in one or more TV programs & 3.049 & 3.393 & -0.344 \\
\hline 25 & All presenters and news anchor uphold the value of civility & 3.209 & 3.505 & -0.296 \\
\hline 26 & Presenter of every program can convey information properly & 3.118 & 3.483 & -0.365 \\
\hline 27 & There are programs that are not available in national and international TV stations & 3.008 & 3.417 & -0.409 \\
\hline 28 & $\begin{array}{l}\text { Broadcasting holiday greeting and/or customizing the display in any religious } \\
\text { holidays }\end{array}$ & 3.159 & 3.436 & -0.277 \\
\hline 29 & Delivering informative program and providing comprehensive knowledge & 3.121 & 3.518 & -0.398 \\
\hline 30 & Broadcasting Indonesian culture (either local culture or other cultures) & 3.201 & 3.568 & -0.367 \\
\hline 31 & Delivering meaningful and educative programs promoting good behavior & 3.142 & 3.564 & -0.422 \\
\hline
\end{tabular}


Jurnal Bisnis \& Manajemen, 2018, Vol. XIX, No. 1, 37-46

Available at: http://journal.feb.unpad.ac.id/index.php/jbm
JURNAL BISNIS \& MANAJEMEN

ISSN 1412 - 3681

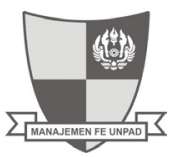

Local Public TV funding sources are from government and advertising. The target audience is the wide society of all segments. Local Private TV is a local TV that is fully operated and owned by Private Company. Target audience is also wide society all segment especially for business purpose. The samples of Local Private TV are SKTV, AKTV, Bandung TV, CITV, Cirebon TV, RCTV, I-Channel, NTV, Garuda Vision, Kemuning TV, and Jatiluhur TV. Meanwhile. The sample of Local Public TV is TVRI West Java.

\section{Business Model Canvas of Local Private TV Stations in West Java}

The results of in-depth interviews with Local Private TV stations in West Java are made into a business model canvas of the local Private TV stations. Here is the business model canvas of local Private TV stations in West Java for developing local contents based on nine elements of the business model canvas.

The first element is the value proposition. Local TV stations in West Java are consistent in establishing local content in each program aired, responsive in providing pre and after service, and using communication media to maintain a relationship with customers.
The second element is customer segment. The segment of local TV stations in West Java is focused on government agencies, educational institutions, entrepreneurs, communities, artists, organizations, and end-customer.

The third element is key activities. The key activity of local TV stations in West Java is airing the show programs, commercial and advertisement production The fourth element is a key partnership. Local TV stations in West Java run their business activities by working with the other parties, namely end consumers, government agencies, educational institutions, advisory board members, talented people, communities, local artists, community leaders, property leasing services, production house, as well as the state apparatus.

The fifth element is key resources. In carrying out their activities, local TV stations in West Java utilize the following resources; human resources (employees), building, tower transmitter, transmitter, vehicles, personal computers, tools and production equipment such as cameras, lighting, and microphones, etc.

The sixth element is customer relation. The local TV stations maintain a relationship with their customers using the telecommunication media and social

The Business Model Canvas of Local Private TV Stations in West Java, shown in figure 1 as follows:

\begin{tabular}{|c|c|c|c|c|}
\hline \multirow{2}{*}{ 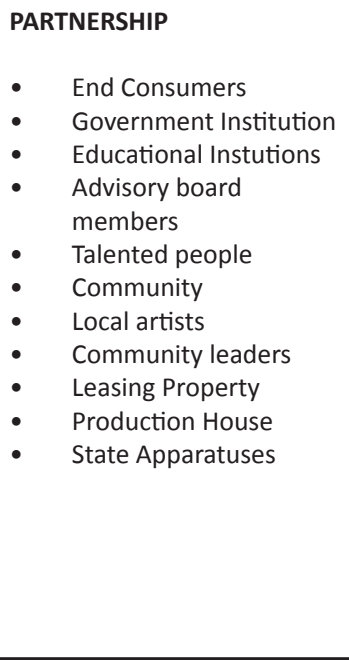 } & $\begin{array}{l}\text { KEY ACTIVITY } \\
\text { - The production process } \\
\text { of tapping } \\
\text { - Live broadcast } \\
\text { - Production of } \\
\text { advertisement and } \\
\text { video clip } \\
\text { - Advertising }\end{array}$ & \multirow[t]{2}{*}{$\begin{array}{l}\text { VALUE PROPOSITION } \\
\text { - } \quad \text { Content consistency in } \\
\text { each program } \\
\text { Responsive service both } \\
\text { pre and after services } \\
\text { Maintain relationship } \\
\text { with customers by } \\
\text { utilizing communication } \\
\text { media }\end{array}$} & $\begin{array}{l}\text { CUSTOMER RELATIONSHIP } \\
\text { Maintain relationship } \\
\text { with customers } \\
\text { by utilizing } \\
\text { telecommunication } \\
\text { media and social media. } \\
\text { Meeting the needs and } \\
\text { desires of customers }\end{array}$ & \multirow{2}{*}{\begin{tabular}{|l} 
CUSTOMER SEGMENTS \\
- West Java society \\
(Sundanese) aged \\
20 years and above, \\
includes: Goverment \\
Agencies Educational \\
Institutions \\
Entrepreneurs \\
Community \\
Organization Artists \\
End-customer
\end{tabular}} \\
\hline & 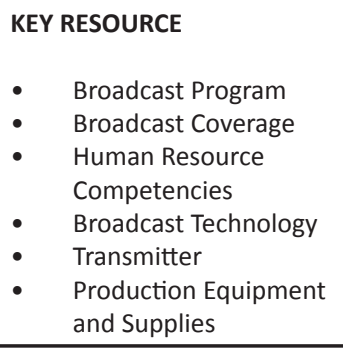 & & $\begin{array}{l}\text { CHANNELS } \\
\begin{array}{l}\text { - } \quad \text { Broadcast } \\
\text { - } \quad \text { TV Channel } \\
\text { - Internet }\end{array}\end{array}$ & \\
\hline \multicolumn{2}{|l|}{$\begin{array}{l}\text { COST STRUCTURE } \\
\begin{array}{ll}\text { - } & \text { Production Cost } \\
\text { - } & \text { Overhead Cost } \\
\text { - } & \text { Operation Cost } \\
\text { - } & \text { Promotion Cost } \\
\text { - } & \text { Maintenance Cost }\end{array}\end{array}$} & \multicolumn{3}{|c|}{$\begin{array}{ll}\text { REVENUE STREAMS } \\
\text { - } & \text { Advertisement or commercial, production of advertising and video clip } \\
\text { - } & \text { Production House } \\
\text { - } & \text { Talk show program } \\
\text { - } & \text { Off-air } \\
\text { - } & \text { Pronsorship } \\
\text { - } & \text { Certain event procurement \& advertorial }\end{array}$} \\
\hline
\end{tabular}




\section{JURNAL BISNIS \& MANAJEMEN}

ISSN 1412 - 3681

media as well as fulfill the needs and desires of their customers.

The seventh element channel. The local TV stations in West Java, especially their marketing departments, get in touch with their customers using several methods such as promotion, media partners, word of mouth, door to door, and barter promo.

The eighth element is the cost structure. This represents the costs incurred by the local TV stations running the business. The costs incurred by local TV stations are for the production of the programs, i.e. for accommodation, paying the presenters, legal, administration, electricity, salaries, paying building or studio rent.

The last element is the revenue stream. The income received by a local TV comes from advertising, production house, talk shows, off-air programs, production of advertising and video clips, sponsorship, profit sharing, certain event procurement, and advertorial.

\section{Business Model Canvas of Local Public TV Stations in West Java}

Here is the business model canvas of local Public TV station in West Java for developing local contents based on nine elements of the business model canvas.

\section{Value Proposition}

The main value of Local Public TV Station is disseminating regional development information hence its can stimulate investors to invest in this region.
Jurnal Bisnis \& Manajemen, 2018, Vol. XIX, No. 1, 37-46

Available at: http://journal.feb.unpad.ac.id/index.php/jbm

\section{Customer Segment}

The Customer Segment of Local Public TV Station are local government, wide society and investors.

\section{Channels}

The Channels to deliver TV programs are through free-to-air broadcast, TV Channels and Internet.

\section{Customer Relationship}

Local Public TV Station maintain relationships with their customers through telecommunication media, social media and internet to interact and capture the customer feedback.

\section{Key Activities}

The key activities of Local Public TV Station are content creations and broadcasting. Content creation can be a form of Live Broadcast, Tapping, Program Production, and News Program Monitoring.

\section{Key partnership}

Key partnerships of Local Public TV Station are local government and advertisers. The role of Local government is to provide development information contents that needed by investors. The role advertisers is to create added revenue.

\section{Key Resources}

The key resources of Local Public TV Station are programs creation and broadcast coverage. Programs creation supported by creativity of human resources, production tools and equipment support. Broadcast coverage supported by transmitter technology.

\section{Cost Structure}

Cost Structure of Local Public TV Station are Production Cost, Operational Cost, Overhead Cost,

\begin{tabular}{|c|c|c|c|c|}
\hline \multirow[t]{2}{*}{$\begin{array}{l}\text { Key Partnerships } \\
\text { - } \quad \text { Advertisers } \\
\text { - } \quad \text { Local Goverment }\end{array}$} & $\begin{array}{l}\text { Key } \text { Activities } \\
\text { - } \quad \text { Broadcast } \\
\text { - } \quad \text { Content creation }\end{array}$ & \multirow[t]{2}{*}{$\begin{array}{l}\text { Value Propotion } \\
\text { - } \quad \begin{array}{l}\text { Disseminating regional } \\
\text { development information }\end{array} \\
\text { - } \quad \begin{array}{l}\text { Provide information for } \\
\text { investors to invest in this region }\end{array}\end{array}$} & $\begin{array}{l}\text { Customer Relationships } \\
\text { - } \quad \text { Telecommunication } \\
\text { Media } \\
\text { - } \quad \text { Social Media } \\
\text { - Internet }\end{array}$ & \multirow[t]{2}{*}{$\begin{array}{l}\text { Customer Segments } \\
\begin{array}{l}\text { Local } \\
\text { Government } \\
\text { - Society-all } \\
\text { segments } \\
\text { Investors }\end{array}\end{array}$} \\
\hline & $\begin{array}{ll}\text { KEY RESOURCE } \\
\text { - } \\
\text { - } \quad \text { Broadcast Program } \\
\text { - } & \text { Human Resource Competencies } \\
\text { - } & \text { Broadcast Technology } \\
\text { - } & \text { Transmitter } \\
\text { - } & \text { Production Equipment and Supplies }\end{array}$ & & $\begin{array}{l}\text { Channels } \\
\text { - } \quad \text { Broadcast } \\
\text { - } \quad \text { TV Channel } \\
\text { - Internet }\end{array}$ & \\
\hline \multicolumn{2}{|l|}{$\begin{array}{l}\text { Cost Structure } \\
\text { 1. Production Cost } \\
\text { 2. Overhead Cost } \\
\text { 3. Operation Cost } \\
\text { 4. Promotion Cost } \\
\text { 5. Maintenance Cost }\end{array}$} & \multicolumn{3}{|c|}{$\begin{array}{ll}\text { - } & \text { Advertising } \\
\text { - } & \text { Product and Services creation for customers } \\
\text { - } & \text { Government Subsidies } \\
\text { - } & \text { Live events }\end{array}$} \\
\hline
\end{tabular}


Jurnal Bisnis \& Manajemen, 2018, Vol. XIX, No. 1, 37-46

Available at: http://journal.feb.unpad.ac.id/index.php/jbm

Promotion Cost, and Maintenance Cost.

\section{Revenue Stream}

The Local Public TV Stations receive revenue from advertising, Products and Services creation for customer, live events and government subsidies. The model is shown in figure 2 .

\section{CONCLUSION}

The local TV viewers still feel unsatisfied with all aspects of the programs offered by the local TV stations in West Java. It is shown that the viewers perceived is lower than the viewers desired. Based on business model canvas, the model business of local private and public TV are almost same. It shown in these nine elements of BMC. Basically the business goal of private and public TV is to create revenue from advertising. We recommend that the Local TV Stations need to create unique and superior programs to elevate the value of local wisdom as uniqueness value proposition. Besides, the local TV Stations need to expand their coverage area to increase amount of viewers. The local TV Stations could expand their broadcasting to Digital TV Channel.

\section{REFERENCES}

Heizer, J., Reinder, B., and Munson, C. (2016). Operations Management (12th ed.). Pearson Education, Inc.

Kaltum, U. \& Widodo, A. (2011). Local TV Goes to Global Market Through Digital Transformation, Academy of Strategic Management Journal, Vol 15, Special Issue 3, Published by Jordan Whitney Enterprises, Inc.

Krumeich, J., Burkhart, T., Werth, D., and Loos, P. (2012). Towards a Component-based Description of Business Models: A State-ofthe-Art Analysis. AMCIS 2012 Proceedings 19. Retrieved through http://aisel.aisnet.
JURNAL BISNIS \& MANAJEMEN

ISSN 1412 - 3681

org/amcis2012/proceedings/EBusiness/19

Metters, R., King-Metters, K., Pullman, M., and Walton. S. (2006). Successful Service Operations management. Thomson SouthWestern.

Osterwalder, A. and Pigneur, Y. (2010). Business Model Generation: A Handbook for Visionaries, Game Changers, and Challengers. New Jersey: Wiley and Sons.

Parasuraman, A., Zeithaml, V. and Berry, L. (1988). SERVQUAL: a multiple-item scale for measuring customer perceptions of service quality, Journal of Retailing, 64, 12-40.

Prihtiyani, E. (2011). The Indonesian Ad Spending Highest in Southeast Asia, Kompas.com, Tuesday, December 20, 2011, [online], http://bisniskeuangan.kompas.com/ $\mathrm{read} / 2011 / 12 / 20 / 14403449 /$.

Rinowati, NA. (2011). The existence of Local TV, Department of Communication Studies, University of Diponegoro, Semarang.

Telkom R \& D Center. (2010). Assessment Services NetTV, PT Telekomunikasi Indonesia Tbk., R \& D Center, Bandung, Indonesia.

Wheelen, T.L., Hunger, J.D, Hoffman, A.N., Bamford, C.E. (2015). Strategic Management and Business Policy: Globalization, Innovation, and Sustainability, 14th Edition, Global Edition, Pearson.

Zeithaml, V. and Bitner, M. (2003) Service Marketing: Integrating Customer Focus across the Firm, McGraw-Hill, New York. 